\title{
THE INFLUENCE OF A MUNICIPAL SOLID WASTE LANDFILL ON GROUNDWATER QUALITY: A MODELING CASE STUDY FOR RÂURENI-RÂMNICU VÂLCEA (ROMANIA)
}

\author{
I. MARINOV ${ }^{1} \&$ A. M. MARINOV ${ }^{2}$ \\ ${ }^{1}$ Department of Earth and Environmental Science, University of Pennsylvania, Philadelphia, USA. \\ ${ }^{2}$ Department of Hydraulics, Hydraulic Machinery and Environmental Engineering, \\ University Politehnica of Bucharest, Bucharest, Romania.
}

\begin{abstract}
Municipal solid waste landfills are potential long-term sources of pollution for both humans and the environment and need to be managed properly both during their lifetime and after closure. This paper analyzes the influence of the Râureni-Râmnicu Vâlcea landfill (Romania) on the concentration of pollutant reaching the groundwater and the nearby Olt River. Prediction of contaminant concentration in groundwater is based on a simple mathematical model of solute transport. Model parameters are determined from field data and scale analysis. Despite its recent closure after 32 years of activity, this landfill has the potential to continue to pollute both the Olt River and the groundwater for decades. Sensitivity analyses are performed to determine the impact of varying the dispersivity coefficients on the resulting contaminant transport and distribution in the aquifer. Aquifer pollution is predicted for twenty years beyond the landfill closure. Enhanced landfill monitoring and establishment of a shared data portal for Romanian environmental data is highly recommended.

Keywords: Advection-dispersion equation, aquifer, landfill, peclet number, pollution, scale effect of dispersion, solute transport.
\end{abstract}

\section{INTRODUCTION}

Municipal solid waste (MSW) landfills are sites serving as a depository of urban solid waste. Landfills management and the contamination of groundwater by leachate are now recognized as some of the greatest problems associated with environmental operation of MSW.

Precipitation, surface water infiltration or percolating water from land adjacent to landfills can move through the solid waste, vegetation and multiple soil layers, mobilizing organic and inorganic compounds on the way and resulting in leaching to the groundwater below the landfill and ultimately to local streams and rivers.

Leachate is a strongly polluted wastewater, with chemical and biochemical components dependent on the composition of landfilled waste and the extent of degradation and decomposition. Main types of pollutants typically found in MSW landfill leachate include: organic compounds, inorganic macro components (calcium, magnesium, sodium, potassium, ammonium, iron, manganese, chloride, sulfate); heavy metals (cadmium, chromium, copper, lead, nickel, zinc); pathogenic microorganisms [1-4]. Landfill regions are typically characterized by increased hardness, alkalinity, and total dissolved solids concentrations. Biological decomposition of waste products results in increased emissions of methane, carbon dioxide, ammonia, and hydrogen sulfide. Short and long-terms variations in climate, moisture content, temperature, hydrogeology, waste composition, and its changing in time will induce leachate variations from one landfill to another $[5,6]$ or seasonal variations within the same landfill [7]. The leachate from an MSW landfill can be minimized if water from the above sources is steered away from the fill material via well-engineered drains or channels or with appropriate chemical treatments [6]. 


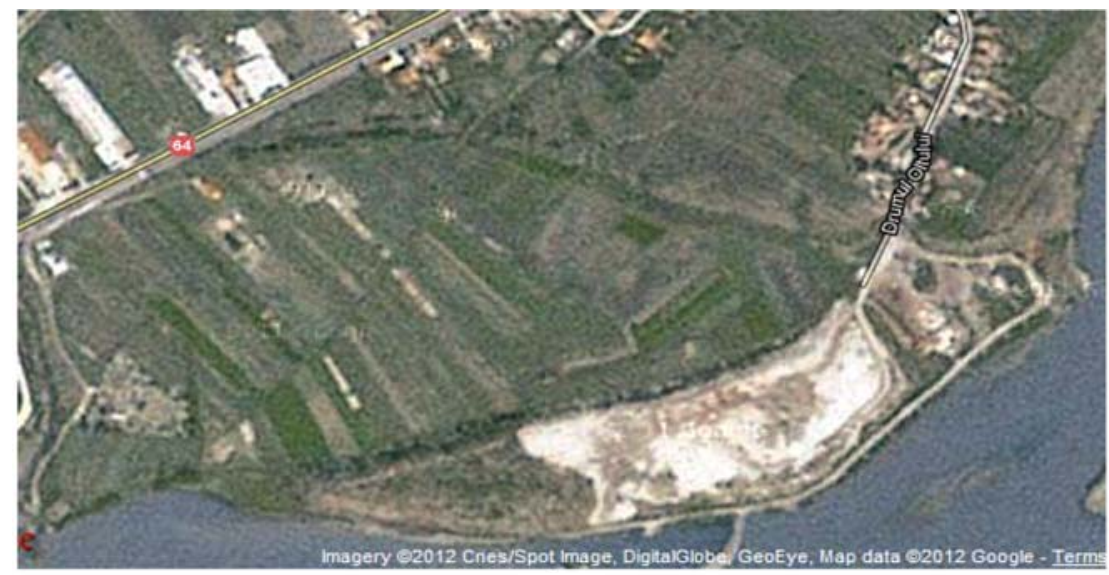

(a)

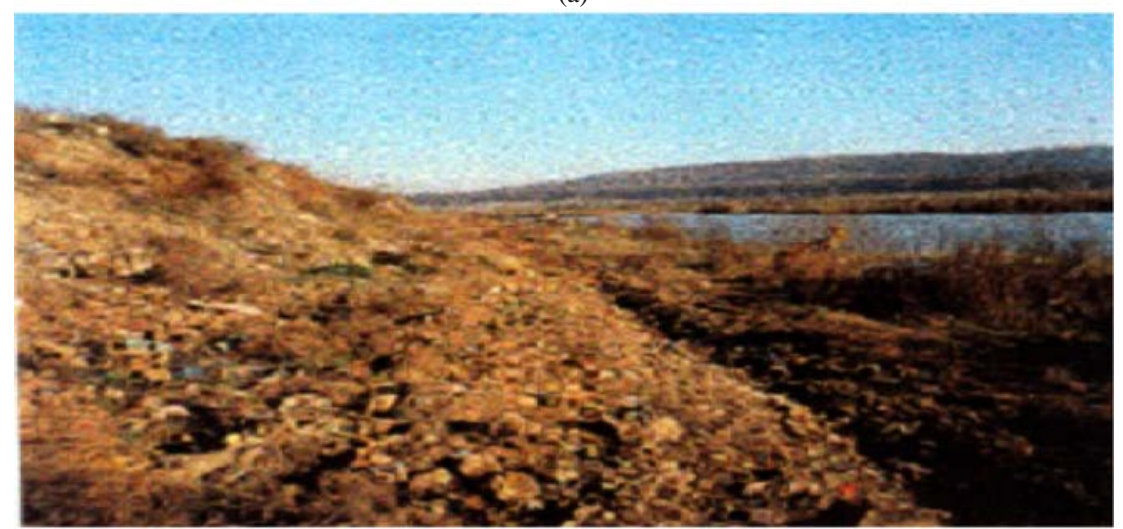

(b)

Figure 1: (a) Satellite image showing the Râureni landfill location relative to the river Olt. (b) Photography of the SE landfill limit (at 2-3 m from the Olt River).

Few of the existing landfills in Romania can be regarded as sanitary landfills, which are designed and constructed according to EU engineering and legal environmental specifications $[8,9]$. Landfills built without engineered liners and leachate collection systems and ill-maintained landfills pose a long-lasting risk for humans and the environment through significant gas emissions and leaching.

The town of Râmnicu Vâlcea (pop 120,000) extends from the foothills of the South Carpatians to the banks of the Olt, a tributary of the Danube and one of Romania's main watercourses. While the town is a popular tourist destination - due to a few well known spas and health resorts in the area - and an important industrial centre, it is plagued by a historically inefficient system of household waste management, e.g. $20 \%$ of inhabitants living without regular waste disposal services and a large number of dumps situated near inhabited areas.

The landfill for household waste of the town of Râmnicu Vâlcea is situated $6 \mathrm{~km}$ outside the town on the right hand side of the major valley of the Olt River, with the waste material as close as $2 \mathrm{~m}$ to the river (Fig. 1a and b). The landfill was active from 1978 until January 2010 and covers about 11.5 ha. The impact of the Râureni landfill on the environment over the last three decades has been due to 
1. Improper disposing of waste material in the landfill, without preliminary processing of waste material (sorting, treatment or recycling) and without appropriate compacting, resulting in reduced control over the long-term consolidation of the landfill and the resulting leakage.

2. Uncontrolled flow of precipitation through the landfill resulting in time variable, hard to quantify leakage. Most of the leakage historically infiltrated to the soil and groundwater, with a small percent collected by the draining system and directly evacuated into the Olt River. Chemical and biological measurements in the Olt River over time have shown higher pollutant concentrations downstream of the landfill compared to upstream of the river.

3. Uncontrolled emissions of gaseous pollutants (primarily methane) that produced occasional spontaneous fires at the surface of the landfill, especially during the summer when temperatures in the waste material can reach $70-80^{\circ} \mathrm{C}$.

4. Unpleasant heavy odors for hundreds of meters around the landfill.

Because of all these compounding factors, the long-term rehabilitation of the landfill will be rather lengthy.

Since Romania recently entered the EU, the Romanian legislation regarding surface and groundwater as well as landfills has aligned with the European legislation [10]. The establishment of new landfills must now conform to EU standards, in that they have to be properly located, operated, and monitored especially in regions with high rainfall rates and shallow water tables. Old landfills that do not obey EU environmental quality indicators must be closely monitored and depending on the situation, either rehabilitated or closed.

As part of the 'Integrated waste management in Râmnicu Vâlcea' project co-financed by the European Commission, in January 2010 the municipality closed the Râureni landfill after 32 years of functioning, and created a new ecological depot at Feteni with a capacity of $10^{6} \mathrm{~m}^{3}$ and a life expectancy of 19 years. The closing of the old Râureni landfill involved a detailed series of steps which included building an impermeable membrane at the surface to prevent rain water infiltration in the waste deposit; building a drainage system to transport the rain water collected at the membrane surface; building a drainage system for the fermentation by-products resulting from microbiological waste decomposition; building a plant to collect and burn the fermentation by-products; adding a layer of cultivated soil to the landfill surface.

Here we make a projection of the impact of the Râureni-Râmnicu Vâlcea landfill on the quality of groundwater in the proximity of the landfill, during its lifetime and twenty years beyond its closure. We base our prediction of contaminant concentration in groundwater on a mathematical model of solute transport, calibrated with hydrological data specific to our region. We analise the sensitivity of the aquifer leachate plume to varying dispersivity coefficients and flow directions in the aquifer.

\section{THE RÂURENI LANDFILL AND THE UNDERLYING AQUIFER: A HYDROGEOLOGICAL DESCRIPTION}

The landfill covers about 11.5 ha, with a height of 3-15 m, a width of $50-150 \mathrm{~m}$ and a maximum length of about $600 \mathrm{~m}$. Figure 2 shows the location of the landfill and of the observation wells.

The waste deposit is located in a roughly $1 \mathrm{~km}$ wide alluvial meadow that runs parallel to the river Olt. Hydro-geologically, the region has a lithological structure characteristic for a large river valley and terraces, with typical alluvial deposits. Silt and clay in fine particle sizes dominate the soil structure from the soil surface up to a depth of 2.5-3 m, while coarse sand, gravel, 


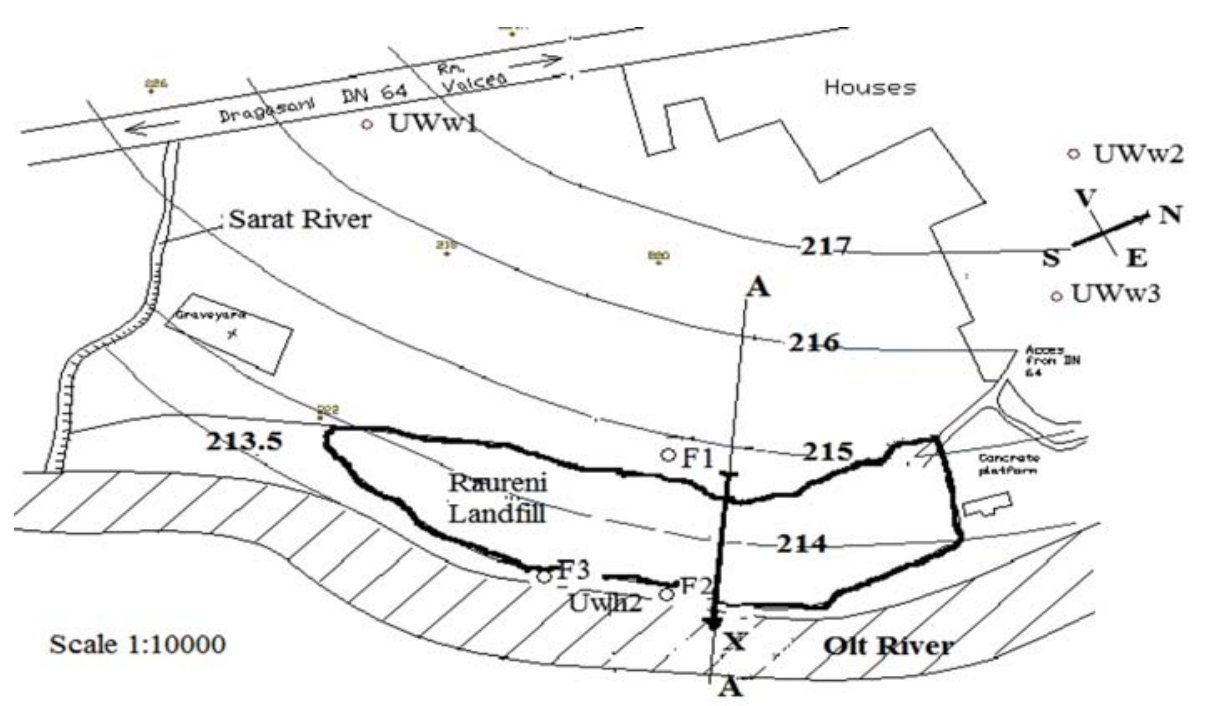

Figure 2: The landfill position and steady-state water-table elevation contours (scale 1:10000). The $x$ direction is chosen along the $\mathrm{A}-\mathrm{A}$ axis.

boulders and fractured stone dominate below $3 \mathrm{~m}$. The hydraulic conductivity of the alluvial deposits in the region ranges from $45 \mathrm{~m} /$ day for the sandy deposits to $450-700 \mathrm{~m} /$ day for gravel.

The Râureni landfill is situated at an average altitude of $220 \mathrm{~m}$ and is located above a shallow unconfined aquifer. The aquifer is about $7 \mathrm{~m}$ thick beneath the landfill, and consists of three soil layers. The water-table level under the landfill and in the nearby river Olt is around $214 \mathrm{~m}$ (referenced to the Black Sea level). Piezometers at various locations in our area are used to measure the elevation of the piezometric water level above datum or hydraulic head h. Equal piezometric headlines corresponding to free water-table elevation contours in the aquifer are shown in Fig. 2, for steady-state conditions. We analise the flow regime in this aquifer and the dispersion of leachate percolated from the landfill, under various hydrologic conditions.

The Olt River channel is in direct contact with the unconfined aquifer and hence may recharge the groundwater or receive discharge from the groundwater depending on their relative water-table levels. Most of the time the aquifer flow passing underneath the landfill is towards the river, resulting in pollution of the Olt River through the aquifer boundaries. During periods of heavy-river flow (floods) the Olt River supplies the phreatic aquifer, and the quality of underground water in the neighbor village area can be affected by the landfill leachate.

The velocity in the aquifer in the $x$ direction $\left(v_{x}\right)$ is determined from the water-table elevation contour map. First, the hydraulic gradient $d h / d l$, in the direction of the flow $l$, (A-A profile in Fig. 2) is estimated as (0.006) for average water level in the river and aquifer flow towards the river or at $(-0.006)$ if the river level is $1 \mathrm{~m}$ above the annual average and the flow is towards the aquifer.

The specific discharge (Darcy flux) $q$ (m/day), which is the volumetric flow rate per cross-sectional area, is determined from Darcy's law, the fundamental relation describing flow in porous media:

$$
q=-K \frac{d h}{d l}
$$


Table 1: Hydrological properties estimated for the three layers of the aquifer: effective porosity $n_{e}$, hydraulic conductivity $K$, specific discharge $q$, interstitial velocity $v_{x}$, and average particle diameter $d$.

\begin{tabular}{llllllrl}
\hline Layer & $\begin{array}{l}\text { Position in } \\
z \text { direction }\end{array}$ & Composition & $n_{e}$ & $\begin{array}{l}K \\
\mathrm{~m} / \mathrm{day}\end{array}$ & $\begin{array}{l}q \\
\mathrm{~m} / \mathrm{day}\end{array}$ & $\begin{array}{r}v_{x} \\
\mathrm{~m} / \mathrm{day}\end{array}$ & $\begin{array}{l}d \\
\mathrm{~mm}\end{array}$ \\
\hline 1 & $0.0-2.5 \mathrm{~m}$ & coarse sand & 0.27 & 45 & 0.27 & 1.0 & 1.0 \\
2 & $2.5-5.0 \mathrm{~m}$ & gravel & 0.25 & 450 & 2.7 & 10.8 & 4 \\
3 & $5.0-7.0 \mathrm{~m}$ & $\begin{array}{l}\text { boulders and } \\
\text { blocks }\end{array}$ & 0.20 & 10 & 0.06 & 0.3 & 100 \\
& & & & & & \\
\hline
\end{tabular}

where the hydraulic conductivity $K(\mathrm{~m} /$ day) is estimated for each of the three aquifer layers as a function of porous material composition (Table 1).

Finally, the interstitial velocity through the aquifer's pores in the $x$ direction is calculated in Table 1 from

$$
v_{x}=\frac{q}{n_{e}}
$$

where $n_{e}$ is the effective porosity, again a function of layer composition.

Average concentrations of pollutants from a set of wells are shown in Table 2. F1, F2 and F3 are observation wells on the margins of the landfill; UWw3 is a local well in the northern part of the domain. Measurements from well F3 on the banks of the Olt indicate values above the admissible range for heavy metals, chloride, nitrite, $\mathrm{CCO}-\mathrm{Cr}$ (chemical consumption of oxygen determined with $\mathrm{K}_{2} \mathrm{Cr}_{2} \mathrm{O}_{7}$ ), CCO-Mn (chemical oxygen consumption determined from $\left.\mathrm{KMnO}_{4}\right)$. At $\mathrm{F} 1$ and $\mathrm{F} 2$ various nutrients $(\mathrm{N}+\mathrm{K})$ and chloride are above admissible values. Historical Olt River measurements upstream and downstream of the landfill indicate increased coliform bacteria, E. coli and faecal streptococcus due to the presence of the landfill, as shown by measurements at well F3.

\section{ESTIMATING DISPERSION PARAMETERS FOR OUR SYSTEM}

The two-dimensional equation of mass transport for a conservative solute that does not interact with the porous media or undergo biological or radioactive decay, and evolves in a vertical plane $(x, z)$ is:

$$
\frac{\partial}{\partial x}\left(D_{L} \frac{\partial C}{\partial x}\right)+\frac{\partial}{\partial z}\left(D_{T} \frac{\partial C}{\partial z}\right)-\left[\frac{\partial}{\partial x}\left(v_{x} C\right)+\frac{\partial}{\partial z}\left(v_{z} C\right)\right]=\frac{\partial C}{\partial t}
$$

where $C(x, z, t)$ is the pollutant concentration, $t$ is time since the pollution started; $D_{L}\left(\mathrm{~L}^{2} / \mathrm{T}\right)$ and $D_{T}\left(\mathrm{~L}^{2} / \mathrm{T}\right)$ are the longitudinal (along $x$ ) and the transverse (vertical) hydrodynamic dispersion coefficients, respectively. In our setup we can disregard the advective flow in the $z$ direction $\left(v_{z}\right.$ $=0$ ) which typically comes from rain and is in our area of the order of maximum $714 \mathrm{~mm} / \mathrm{year}$, orders of magnitude smaller than the estimated $x$ directional flow rate ( $q$ in Table 1). In a homogeneous medium with a uniform velocity field $\left(v_{x}\right)$ in $x$ direction, eqn (3) becomes:

$$
D_{L} \frac{\partial^{2} C}{\partial x^{2}}+D_{T} \frac{\partial^{2} C}{\partial z^{2}}-v_{x} \frac{\partial C}{\partial x}=\frac{\partial C}{\partial t}
$$


Table 2: Average concentrations of pollutants in the observation wells shown in Fig. 2 (for year 2009), in the proximity of the landfill.

\begin{tabular}{llccccc}
\hline & & \multicolumn{3}{c}{ Observation wells (see Fig. 2 for locations) } \\
\cline { 3 - 7 } Chemical & & & & & & Admissible \\
component & Units & $\mathrm{F} 3$ & UWw3 & $\mathrm{F} 1$ & $\mathrm{~F} 2$ & values \\
\hline $\mathrm{pH}$ & $\mathrm{mg} / \mathrm{L}$ & 7.62 & - & 7.4 & 7.6 & $6.5-7.4$ \\
$\mathrm{NO}_{3}^{-}$ & $\mathrm{mg} / \mathrm{L}$ & 11.2 & 3.0 & 8 & 8 & 45 \\
$\mathrm{NO}_{2}^{-}$ & $\mathrm{mg} / \mathrm{L}$ & 0.25 & 0 & 0.2 & 0.7 & 0 \\
$\mathrm{NH}_{4}^{+}$ & $\mathrm{mg} / \mathrm{L}$ & - & 0 & 2.3 & 1.5 & 0 \\
$\mathrm{PO}_{4}{ }^{3-}$ & $\mathrm{mg} / \mathrm{L}$ & - & 0 & - & - & 0.1 \\
$\mathrm{SO}_{4}{ }^{--}$ & $\mathrm{mg} / \mathrm{L}$ & 78.7 & - & 87 & 87 & 200 \\
$\mathrm{CCO}-\mathrm{Cr}$ & $\mathrm{mg} / \mathrm{L}$ & 362.9 & 12.9 & - & - & 10 \\
$\mathrm{CCO}-\mathrm{Mn}$ & $\mathrm{mg} / \mathrm{L}$ & 48.0 & - & - & - & 2.5 \\
$\mathrm{~N}+\mathrm{K}$ & $\mathrm{mg} / \mathrm{L}$ & - & - & 68.89 & 96.37 & - \\
$\mathrm{Cl}$ & $\mathrm{mg} / \mathrm{L}$ & 680.0 & - & 298.2 & 156.2 & 250 \\
$\mathrm{Cr}$ & $\mathrm{mg} / \mathrm{L}$ & 0.08 & 0 & - & - & 0.05 \\
$\mathrm{~Pb}$ & $\mathrm{mg} / \mathrm{L}$ & 0.09 & 0 & - & - & 0.05 \\
$\mathrm{Cu}$ & $\mathrm{mg} / \mathrm{L}$ & 0.709 & 0.031 & - & - & 0.05 \\
$\mathrm{Ni}$ & $\mathrm{mg} / \mathrm{L}$ & 0.212 & 0 & - & - & 0.1 \\
$\mathrm{Cd}$ & $\mathrm{mg} / \mathrm{L}$ & 0.010 & 0 & - & - & 0.005 \\
$\mathrm{Zn}$ & $\mathrm{mg} / \mathrm{L}$ & 0.020 & 0.005 & - & - & 5.0 \\
coliform bacteria & $\mathrm{CFU} / 100 \mathrm{~cm}^{3}$ & $>16$ & 0 & - & - & $<10$ \\
$E$. coli & $\mathrm{CFU} / 100 \mathrm{~cm}^{3}$ & $>16$ & 0 & - & - & $<2$ \\
Faecal strepto-- & $\mathrm{CFU} / 100 \mathrm{~cm}^{3}$ & $>16$ & 5 & - & - & $<2$ \\
coccus & & & & & & \\
\hline & & & & &
\end{tabular}

Evaluating appropriately the $D_{L}$ and $D_{T}$ coefficients is one of the key issues in groundwater research; these values critically determine solute transport in porous media. Hydrodynamic dispersion is the sum of mechanical (convective) dispersion and molecular diffusion. The longitudinal and transverse hydrodynamic dispersion coefficients are given by:

$$
\begin{aligned}
& D_{L}=a_{L}|\vec{v}|+\omega D_{d}=a_{L}\left|v_{x}\right|+\omega D_{d} \\
& D_{T}=a_{T}|\vec{v}|+\omega D_{d}=a_{T}\left|v_{x}\right|+\omega D_{d}
\end{aligned}
$$

where $\alpha_{L}$ and $\alpha_{T}$ are dispersitivity coefficients and $\omega$ is the tortuosity factor. We assume here an experimentally determined average value $\omega=0.7$ for uniform sand [11].

Dispersivity coefficients $\left(\alpha_{L}, a_{T}\right)$ are empirical factors which quantify how much contaminants stray away from the path of the groundwater; contaminants can be behind or ahead the mean groundwater, giving rise to a longitudinal dispersivity $\left(\alpha_{L}\right)$, or to the sides of the pure advective groundwater flow, leading to a transverse dispersivity $\left(\alpha_{T}\right)$. For low fluid velocities in the limiting case $v_{x} \rightarrow 0$, solute dispersion is determined by molecular diffusion: $D_{L}=D_{T}=\omega D_{d}$. Conversely, for high values of $v_{x}$ dispersion becomes dominant and the contribution of diffusion can be neglected. 
Previous experimental and theoretical research has established that $D_{L}$ and $D_{T}$ can be expressed as functions of the Peclet number [11-16]. The Peclet number is a dimensionless number that relates the effectiveness of mass transport by advection to the effectiveness of mass transport by either dispersion or diffusion and has the general form

$$
P e=\frac{v_{x} d}{D_{d}}
$$

where $v_{x}$ is the advective velocity, $d$ is the average diameter of the particles and $D_{d}$ is the coefficient of molecular diffusion.

The relationship between $D_{L} / D_{d}$ and the Peclet number from a large compilation of experimental (laboratory) measurements is shown in the Fig. 3.

In Fig. 3 notice three separate regimes, with advective dispersion controlling the system at high Peclet numbers, advection and diffusion acting together at intermediate Peclet numbers, and pure diffusion for Peclet numbers less than 0.02. The Peclet numbers estimated for our system are shown in Table 3. An analysis of the Peclet numbers in Fig. 3 suggests that for layers ' 2 ' and ' 3 ' dispersion is the predominant process and diffusion can be neglected, such that the dispersion coefficients will be $D_{L}=\alpha_{L}\left|v_{x}\right|$ and $D_{T}=\alpha_{T}\left|v_{x}\right|$.

By contrast, both diffusion and dispersion control layer ' 1 '. In the next section we use a scalar analysis to estimate $\alpha_{L}$ and $\alpha_{T}$ for our flow (Table 3 ). Using these values, the dispersion

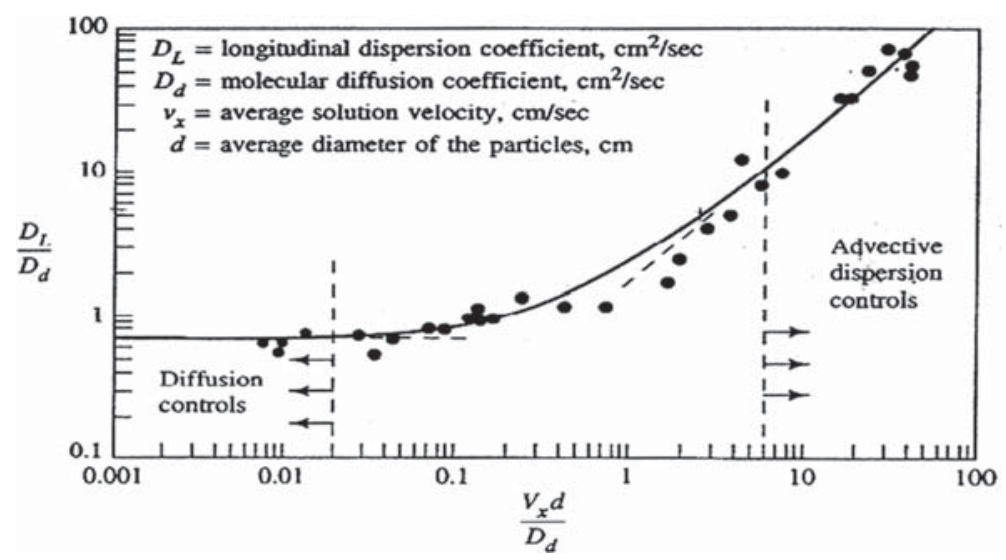

Figure 3: Dimensionless dispersion coefficients $D_{L} / D_{d}$ versus the Peclet number [11].

Table 3: Estimates of: Peclet number, dispersion regime, dispersivity, and dispersion coefficients, in the three-layered aquifer below the Raureni landfill.

\begin{tabular}{lclccrc}
\hline Layer & $P e$ & Transport by & $\begin{array}{c}a_{L} \\
\mathrm{~m}\end{array}$ & $\begin{array}{c}a_{T} \\
\mathrm{~m}\end{array}$ & $\begin{array}{r}D_{L} \\
\mathrm{~m}^{2} / \text { day }\end{array}$ & $\begin{array}{c}D_{T} \\
\mathrm{~m}^{2} / \text { day }\end{array}$ \\
\hline 1 & 5.78 & Diffusion + dispersion & 10 & 0.1 & 10.0 & 0.1 \\
2 & 249.7 & Advective dispersion & 10 & 0.1 & 108.0 & 1.08 \\
3 & 173.41 & Advective dispersion & 10 & 0.1 & 3.0 & 0.03 \\
\hline
\end{tabular}


coefficients for layer ' 1 ' can then be calculated from eqns (5) and (6) where we use a value $D_{d}=2 \times 10^{-9} \mathrm{~m}^{2} / \mathrm{s}$ (for chloride) and a tortuosity of 0.7 .

\section{SCALE EFFECTS OF DISPERSION}

Great differences in dispersivity coefficients are typically observed between laboratory scale and field scale measurements [17]. The dispersivity found for transport through $1 \mathrm{~m}^{3}$ of aquifer is different than that for transport through $1 \mathrm{~cm}^{3}$ of the same aquifer material. The dispersivity that occurs at field-scale flow lengths is known as macro dispersion.

Field measured transversal and longitudinal dispersivities from a large compilation of field measurements are shown against flow length for a variety of soil types (Fig. 4 from Gelhar et al. [17]). The greater the flow length, the larger the value of longitudinal dispersivity needed to fit the data to the advection-dispersion equation. Our model simulates the flow in a vertical domain $(x, z)$. This experimental result suggests that longitudinal dispersivities ( $D_{L}$ in our model) could be estimated to be about 0.1 of the flow length, while transversal vertical diffusivities $\left(D_{T}\right.$ in our model) are about $1 / 100$ of the longitudinal dispersivity.

The width of the Râureni landfill varies from $50 \mathrm{~m}$ to $150 \mathrm{~m}$. Given average width and height of $100 \mathrm{~m}$ and $7 \mathrm{~m}$, respectively, the Gelhar et al. [17] scaling in Fig. 4 suggests for our longitudinal dispersivities: $a_{L}=0.1 \cdot 100 \mathrm{~m}=10 \mathrm{~m}$ and for transversal-vertical dispersivities $a_{T}=a_{L} \cdot 0.001=0.01 \mathrm{~m}$ for a $100 \mathrm{~m}$ scale length. These values are used to calculate the

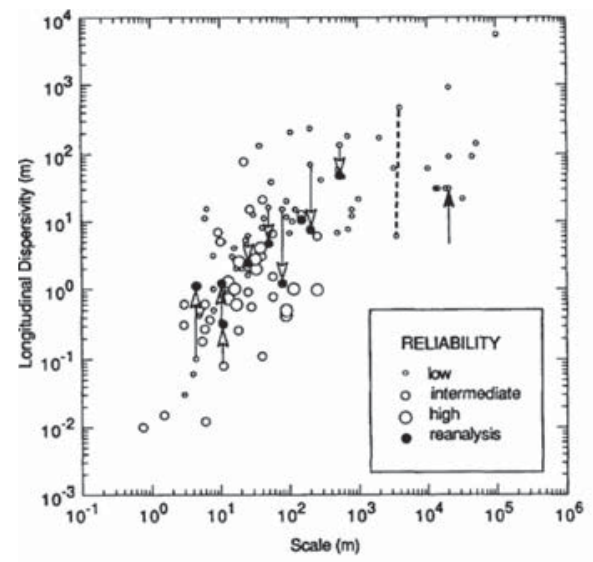

(a)

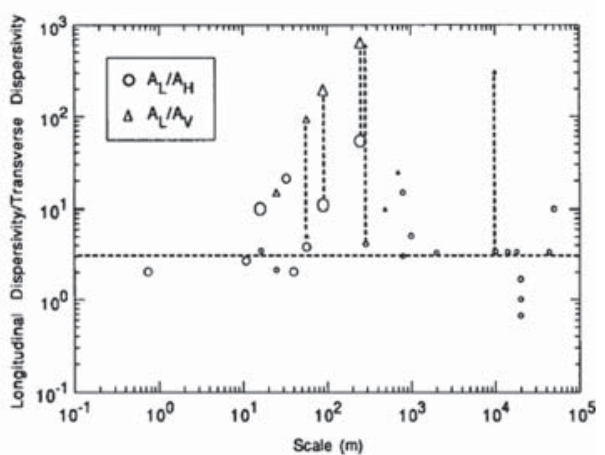

(b)

Figure 4: (a) Longitudinal dispersivity $a_{L}$ versus typical field-scale flow lengths. Arrows indicate reported values at tails and corresponding values from reanalysis at heads. (b) Ratio of longitudinal $\alpha_{L}$ to horizontal and vertical transverse dispersivities; largest symbols are high reliability and smallest symbols are low reliability. Vertical dashed lines connecting two points indicate sites where all three components of the dispersivity tensor have been measured. Horizontal dashed line indicates a ratio of $10 / 3$, which has been widely used in numerical simulations [17]. 
dispersion coefficients in Table 3, in agreement with our dispersion regime discussion in Section 3.

\section{MODEL RESULTS}

The mathematical problem is defined by the advection-dispersion equation for solute transport

$$
D_{L}(z) \frac{\partial^{2} C(x, z, t)}{\partial x^{2}}+D_{T}(z) \frac{\partial^{2} C(x, z, t)}{\partial z^{2}}-v_{x}(z) \frac{\partial C(x, z, t)}{\partial x}=\frac{\partial C(x, z, t)}{\partial t}
$$

written for each of the three layers, using the $v_{x}$ values for each layer calculated in Table 1. Dispersion coefficients are calculated in agreement with the dispersion regime (Table 3):

$$
\begin{aligned}
& \text { for layer '1': } D_{L}(z)=\alpha_{L}\left|v_{x}(z)\right|+\omega D_{d}, D_{T}=a_{T}\left|v_{x}(z)\right|+\omega D_{d} \text {, } \\
& \text { for layers '2' and ' } 3 \text { ': } D_{L}(z)=\alpha_{L}\left|v_{x}(z)\right|, D_{T}=\alpha_{T}\left|v_{x}(z)\right|
\end{aligned}
$$

We integrate numerically eqn (8) using initial and boundary conditions specified for our problem. We assume, in the Fig. 5a, a $160 \mathrm{~m}$ long and $7 \mathrm{~m}$ deep aquifer domain along the A-A vertical profile depicted in Fig. 2 (in the flow direction, $x$ ). The rain water leaks through the landfill activating chemical and biochemical elements and producing leachate; the leachate concentration depends on the amount and type of waste deposits.

The watertable is located at $0.3-1.0 \mathrm{~m}$ under the bottom of the landfill. The leachate crossing the watertable line (MN in Fig. 5a) between coordinates ( $x=40 \mathrm{~m}$ and $z=0 \mathrm{~m}$ ) and $(x=150 \mathrm{~m}$ and $z=0 \mathrm{~m})$ is the pollution source for our aquifer model. Since we do not explicitly model the flow in the landfill, the leachate is taken into account through the boundary condition at $\mathrm{z}=0$ (line $\mathrm{MN}$ ).

We focus our analysis on chloride $\left(\mathrm{Cl}^{-}\right)$, an inorganic anion which is present in our landfill leachate at high concentrations (Table 2) $\mathrm{Cl}^{-}$is a conservative leachate constituent (no retardation) that is readily soluble when waste fractions come in contact with water; it is therefore advected, diffused and dispersed by the flow according to eqn (8).

We choose a representative boundary concentration $C_{0}(x, z=0)=1000 \mathrm{mg} / \mathrm{L}$ to represent the continuous chloride leachate source toward the aquifer based on measured values in observation wells in the proximity of the landfill (data from Romanian Water Resource Database - Apele Romane - annual mean data shown in Table 2). The secondary drinking water standard for chloride is $250 \mathrm{mg} / \mathrm{L}$.

The boundary conditions for our specific problem (Fig. 5a) are as follows:

- on the aquifer watertable $(z=0)$ we choose for AM, $C(x=0-40 \mathrm{~m}, z=0 \mathrm{~m})=0$, for MN, $C(x=40-150 \mathrm{~m}, z=0 \mathrm{~m})=C_{0}(x, z=0)$, for NB, $C(x=150-160 \mathrm{~m}, z=0 \mathrm{~m})=0$;

- on the bottom boundary of the aquifer $z=7$ (CD) we impose $\frac{\partial C(x, z, t)}{\partial z}=0$;

- on the vertical boundaries at $x=0(\mathrm{AC})$ and $x=160 \mathrm{~m}(\mathrm{BD})$ we impose $\frac{\partial C(x, z, t)}{\partial x}=0$.

The dispersion equation for the chloride tracer (8) is discretized in time and space in finite differences using the method of alternate directions (ADI) with initial conditions $C(x, z, t=0)$ $=0.01 \mathrm{mg} / \mathrm{L}$ over the entire domain [12]. 


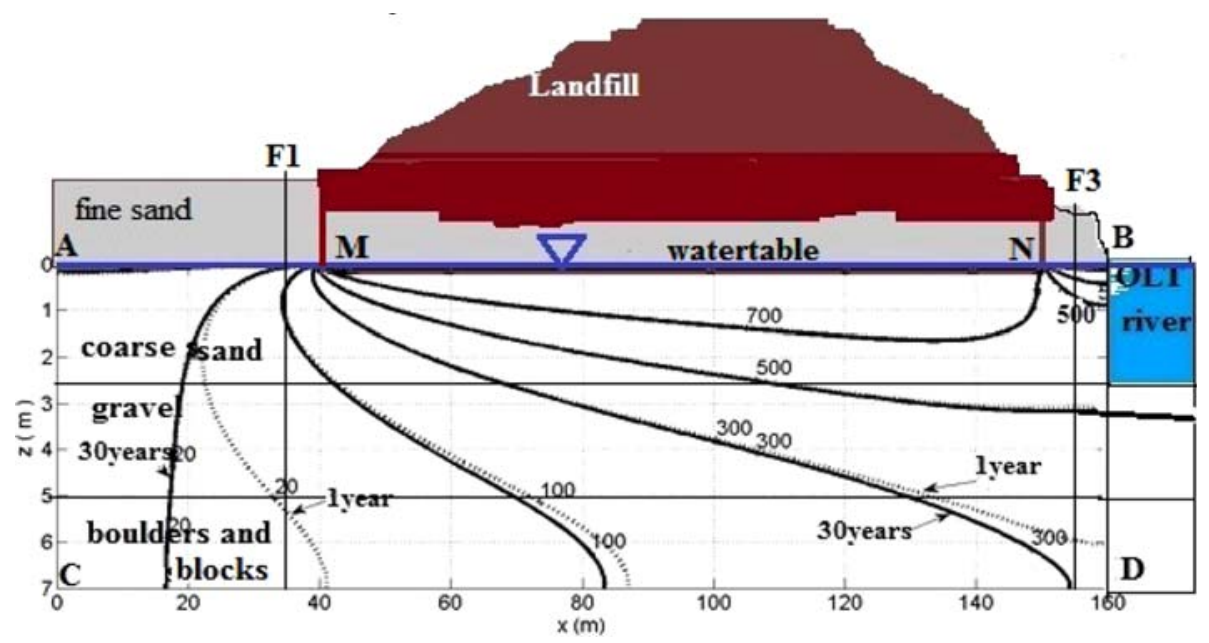

(a)

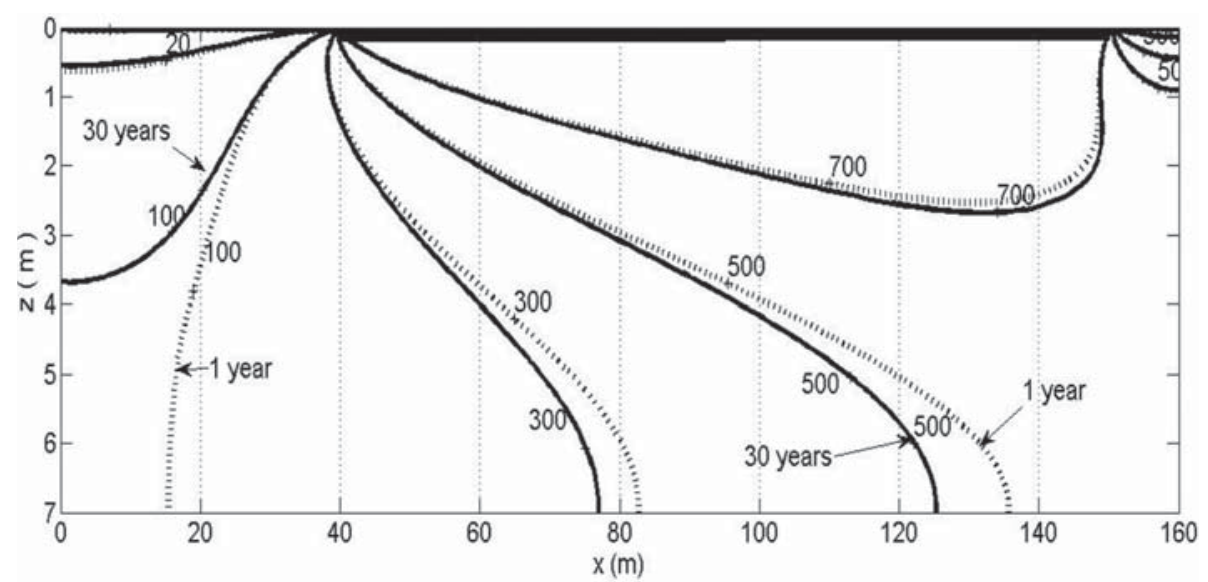

(b)

Figure 5: (a) Equal concentration lines (isochloride) after 1 year (dot lines) and after 30 years (solid lines) of leaching for dispersivities $\alpha_{L}=10 \mathrm{~m}$ and $\alpha_{T}=0.1 \mathrm{~m}$. The landfill is situated between $x=40 \mathrm{~m}$ and $x=150 \mathrm{~m}$ and $1 \mathrm{~m}$ above the surface of the aquifer. The Olt River is the domain boundary at $160 \mathrm{~m}$. Aquifer flow in the domain is to the right, towards the Olt River. A constant chloride leachate $C_{0}=1000 \mathrm{mg} / \mathrm{L}$ is the upper boundary condition. (b) Impact of dispersivities on leachate concentration $(\mathrm{mg} / \mathrm{L})$ in the aquifer. Isochloride lines after 1 year (dot lines) and after 30 years (solid lines) of leaching for dispersivities $\alpha_{L}=20 \mathrm{~m}$ and $\alpha_{T}=0.20 \mathrm{~m}$.

\subsection{Sensitivity studies to dispersion coefficients and flow direction}

We analise the spatial and temporal variation of the leachate plume in the aquifer, assuming that the pollutant is soluble in water and conserved. We first perform a set of sensitivity analyses to determine (a) the impact of varying the longitudinal and transverse dispersivities 
and (b) the impact of varying the direction of the flow on the extent of the leachate plume in the aquifer.

Chloride concentration profiles are shown in Fig. 5a and b, after 1 year (dot line) and after 30 years (solid line) of continuous leaching from the upper boundary MN. Higher longitudinal and transversal dispersivities, $\alpha_{L}$ and $\alpha_{T}$, result in increased plume spreading both in the direction of the flow and in the vertical direction (more sinking toward the bottom), with higher pollutant reaching the Olt River in Fig. 5b compared with Fig. 5a. The pollutant distribution almost reaches steady state after one year and clearly reaches a steady state after 3 years; the concentration profiles between 3 and 30 years are undistinguishable for both dispersivity cases (Fig. 5a and b).

The impact of dispersivities on leachate dispersion is shown in Fig. 6a and b for our two parameter sets. Close analysis shows that the spreading in the horizontal direction is much more pronounced than the vertical spreading of the plume, a natural consequence of our choice of dispersivities, with $\alpha_{L}=100 \alpha_{T}$.

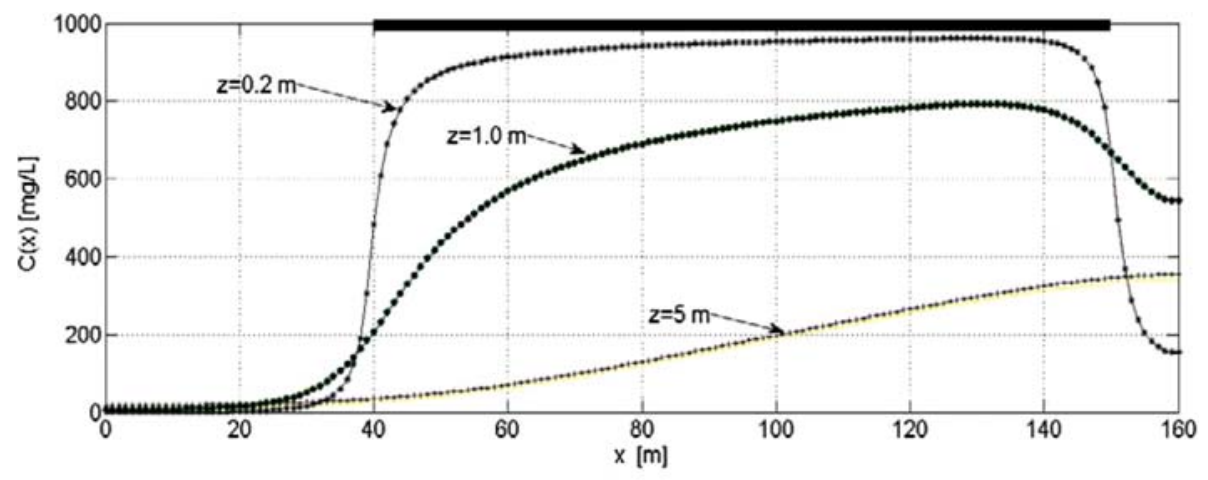

(a)

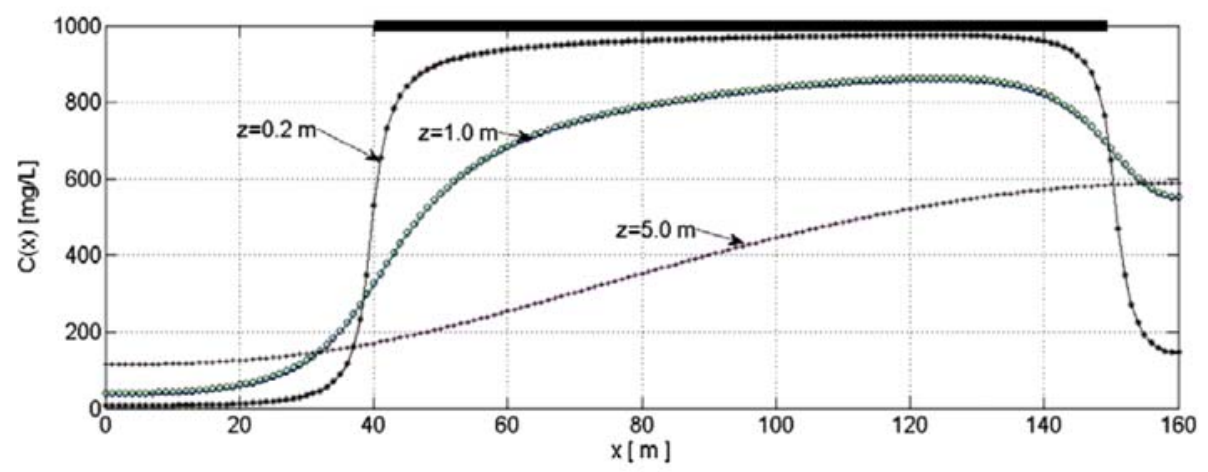

(b)

Figure 6: The impact of dispersivities on leachate dispersion. Leachate concentration versus horizontal distance shown after 30 years of continuous leaching at three different depths in the aquifer for (a) $\alpha_{L}=10 \mathrm{~m}, \alpha_{T}=0.1 \mathrm{~m}$ and (b) $\alpha_{L}=20 \mathrm{~m}, \alpha_{T}=0.20 \mathrm{~m}$. 


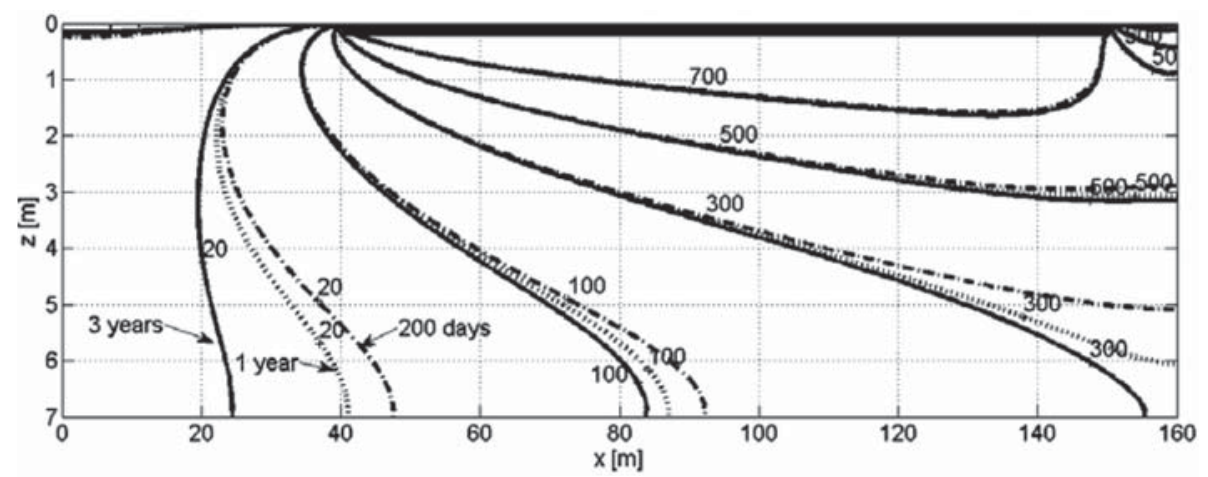

(a)

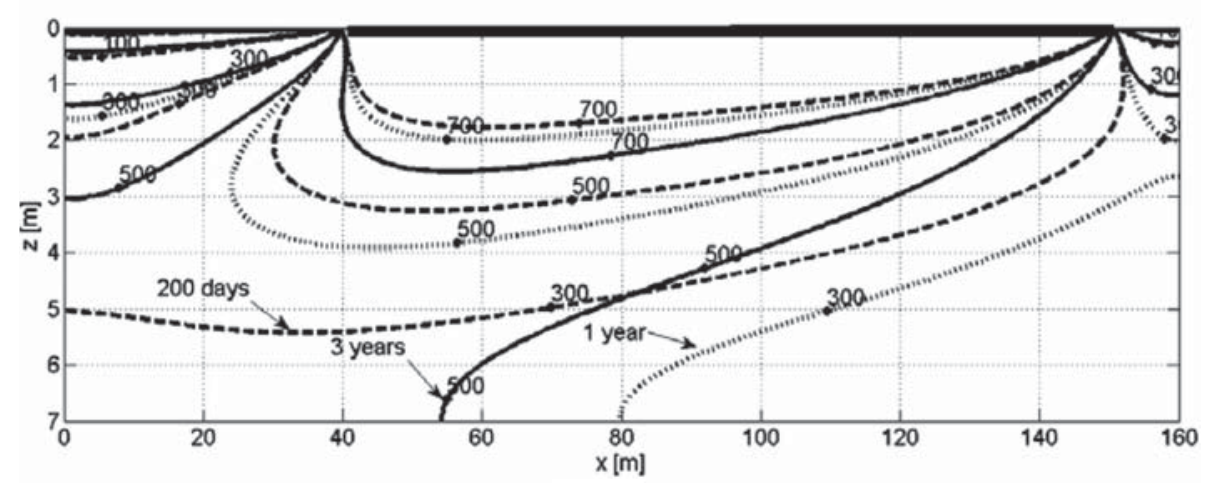

(b)

Figure 7: Flow direction impact on pollutant concentration, in the aquifer. Isochloride lines, shown after 200 days (dashed lines), after 1 year (dot lines), and after 3 years (solid lines) of leaching. Constant leachate at the upper boundary $\left(C_{0}=1000 \mathrm{mg} / \mathrm{L}\right)$ assumed. Here $\alpha_{L}=10 \mathrm{~m}$ and $\alpha_{T}=0.1 \mathrm{~m}$. The Olt River is the domain boundary at $160 \mathrm{~m}$. (a) Aquifer flow to the right, towards the Olt River (usual case). (b) Aquifer flows (at high river levels) to the left, away from the Olt River, and towards the aquifer.

The impact of changing the direction of the aquifer flow - while allowing for the same flow magnitude - on the pollutant plume is shown in Fig. 7. Under usual conditions the flow is towards the Olt River as shown in Fig. 7a and continuous landfill leaching results in gradual pollution of the Olt River (right boundary of the domain), with minimal pollution of groundwater upstream (left boundary of the domain). Under flooding conditions the flow reverses; resulting in about 50\% less pollution of the Olt River but enhanced pollution of the groundwater downstream, towards the neighbor village (left boundary of the domain, Fig. 7b). The overall level of aquifer pollution is much higher and the pollutant plume reaches deeper in the aquifer if the flow is reversed as in Fig. 7b. While the analysis in Fig. 7 is done for multiyear simulations, seasonal or occasional changes in flow direction due to unusually high water levels in the Olt River (for example due to temporary flooding, enhanced spring discharges, etc.) may also result in temporarily enhanced pollution in the aquifers in the vicinity of the Valcea town. 
5.2 Long-term behavior of the aquifer leachate plume after closure

The Râureni waste deposit was closed in 2010 after more than thirty years of continued activity. We next use our model to simulate the advancement of the leached chloride in the aquifer 20 years beyond the landfill closure, assuming a reasonable time varying surface boundary condition for the leachate.

For our particular region the average annual precipitation and evapotranspiration rates are $714 \mathrm{~mm}$ and $680 \mathrm{~mm}$, respectively. Multiplying the resulting net rainwater accumulation in the waste deposit ( $34 \mathrm{~mm} /$ year or $3.4 \mathrm{~cm} /$ year) by the landfill area $(600 \mathrm{~m} \times 150 \mathrm{~m})$ yields an average annual discharge flowing through the landfill of $3060 \mathrm{~m}^{\wedge} 3 /$ year. Water flows at a rate of $3.4 \mathrm{~cm} /$ year through the landfill and towards the aquifer, carrying with it chemical and biological compounds from the landfill and polluting the groundwater.

We further make a simplifying assumption about the leakage discharge behavior after landfill closure, based on the observed long-term behavior of previous capped landfills in similar soils. We assume that after closure the discharge decreases linearly with a rate of $0.085(8.5 \%)$ in the first 8 years and with $0.01525(1.525 \%)$ in the following 12 years. We hypothesize that after the landfill is capped, the pollutant concentration at the aquifer boundary ( $1 \mathrm{~m}$ under the landfill) decreases in time with the same rate as the net water discharge. The resulting curve in Fig. 8 is then used as surface boundary condition for the chloride leachate concentration $(\mathrm{mg} / \mathrm{L})$ in our 50 year model integration.

Results of the 50-year integration are summarized in Figs 9-11 for the case in which $a_{L}=10 \mathrm{~m}$ and $a_{T}=0.1 \mathrm{~m}$. Figure 9 shows isolines of chloride concentration (isochloride) in the aquifer as the aquifer is being closed after 30 years of activity, 8 years after the aquifer was closed and 20 years after closure.

In agreement with the assumed boundary condition (Fig. 8), the drop in pollutant concentration in a vertical profile of the aquifer is initially very rapid but becomes slower over time (Figs 9-11). Eight years after the landfill closure, concentrations of chloride are still above the maximum acceptable $250 \mathrm{mg} / \mathrm{L}$ level in the top one meter of the aquifer. Twenty years after the landfill closure the chloride concentrations in the aquifer have finally fallen to acceptable levels across the vertical profile.

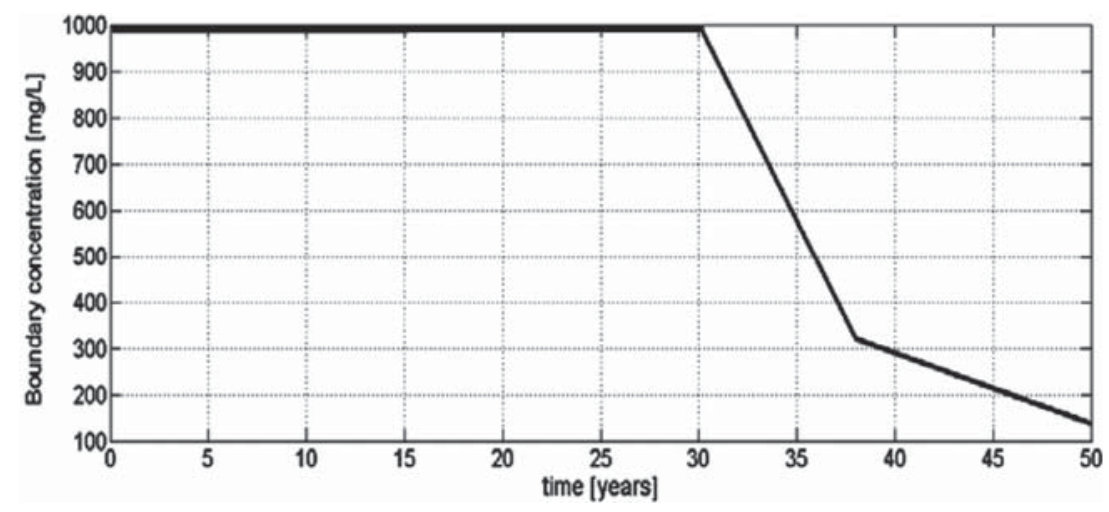

Figure 8: Imposed boundary conditions for the chloride concentration $(\mathrm{mg} / \mathrm{L})$ at the top of the aquifer over 50 years. The landfill was closed after 30 years of activity. 
Our results indicate, as expected, a gradual decrease in the concentration of pollutant in groundwater across the domain. The maximum value (Fig. 10) in the $x$ direction decreases after closure from $950 \mathrm{mg} / \mathrm{L}$ at $0.2 \mathrm{~m}$ after $t=30$ years to $125 \mathrm{mg} / \mathrm{L}$ after 50 years, from $800 \mathrm{mg} / \mathrm{L}$ at $1 \mathrm{~m}$ after $t=30$ years to $110 \mathrm{mg} / \mathrm{L}$ after 50 years, from $360.4 \mathrm{mg} / \mathrm{L}$ at $5 \mathrm{~m}$ after $t=30$ years to $51.1 \mathrm{mg} / \mathrm{L}$ after 50 years.

It is interesting to note the concentration of pollutant at the boundary with the Olt River, i.e. at $x=160 \mathrm{~m}$ (Fig. 10 and Table 4). After 30 years, the steady state concentrations of pollutant

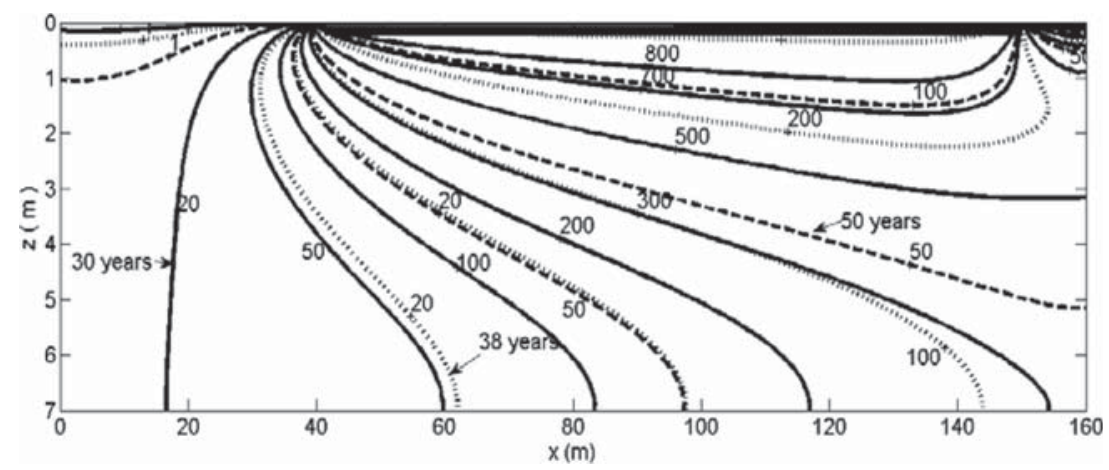

Figure 9: Impact of landfill capping on leachate concentration in the aquifer in a vertical $(x, z)$ section through the aquifer. Concentration of $\mathrm{Cl}^{-}$is shown: (solid line) after 30 years of continuous landfill activity; (dot line) after 38 years - i.e. 8 years after landfill closure; (dashed line) after 50 years, i.e. 20 years after landfill closure.

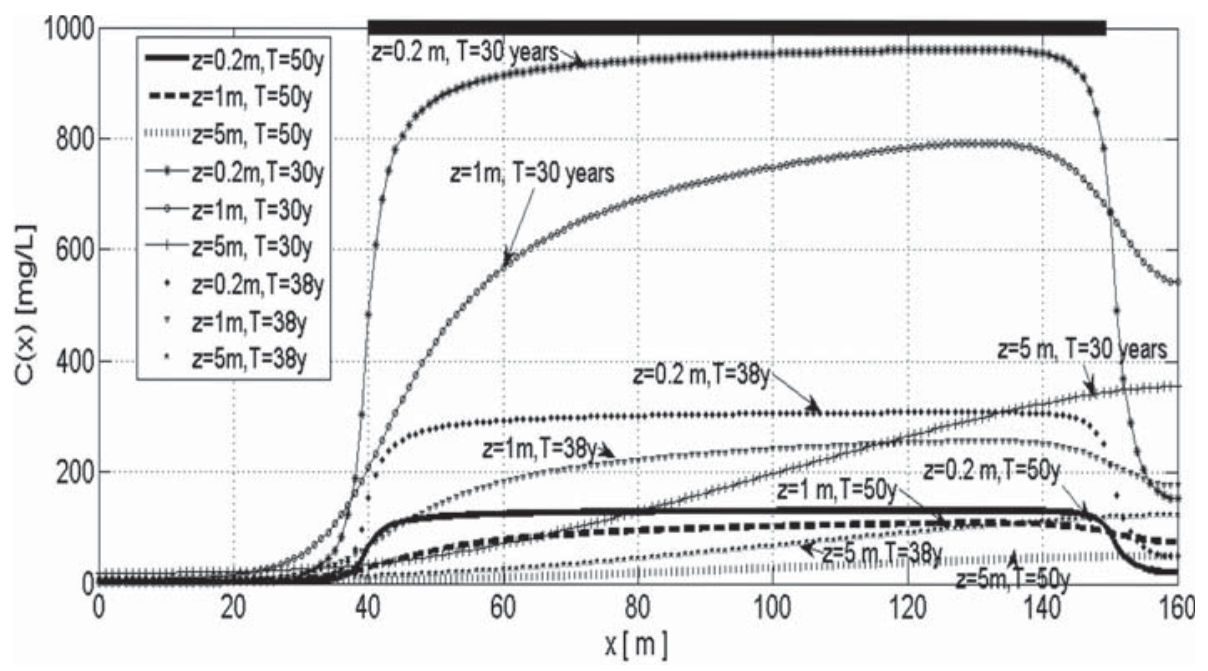

Figure 10: Chloride concentration (mg/L) versus horizontal distance for three different depths in the aquifer, after 30 years of continuous landfill activity, after 38 and 50 years. 


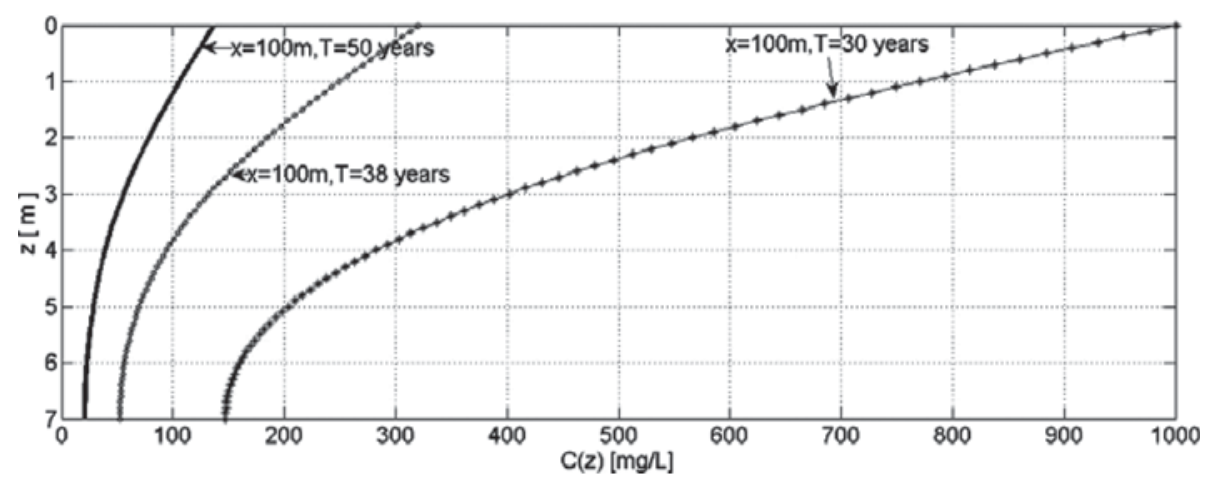

Figure 11: Chloride concentration $(\mathrm{mg} / \mathrm{L})$ versus depth at $x=100 \mathrm{~m}$, the middle of the landfill plume. (* line) after 30 years of continuous landfill activity; (dot line) after 38 years, i.e. 8 years after landfill closure; (solid line) 50 years, i.e. 20 years after landfill closure. Chloride leachate concentration in the aquifer decreases after landfill capping.

Table 4: Pollutant Concentration $\mathrm{C}(x=160 \mathrm{~m}, z, t)$ in $\mathrm{mg} / \mathrm{L}$ at various depths in the aquifer shown at time of landfill closure $(t=30$ years $), 8$ years after closure $(t=38)$ and 20 years after closure $(t=50)$. Capping efficiency 20 years after the closure is also shown [eq. (11)]. A time varying boundary condition for leachate is assumed at the top of the aquifer (see Fig. 8).

\begin{tabular}{lccccccc}
\hline $\mathrm{C}(x=160 \mathrm{~m}, z, t)$ & \multicolumn{8}{c}{$z(\mathrm{~m})$} \\
\cline { 2 - 8 }$t$ (years) & 1 & 2 & 3 & 4 & 5 & 6 & 7 \\
\hline 30 & 525.7 & 582.2 & 513.4 & 429.3 & 360.4 & 317.3 & 303.7 \\
38 & 171.6 & 191.7 & 170.7 & 145.0 & 124.9 & 112.7 & 108.8 \\
50 & 72.63 & 80.16 & 71.49 & 60.18 & 51.10 & 45.48 & 43.68 \\
Efficiency (\%) & 86.18 & 86.23 & 86.09 & 85.98 & 85.82 & 85.66 & 85.62 \\
\hline
\end{tabular}

reaching the river Olt from the aquifer are very high: $525.7 \mathrm{mg} / \mathrm{L}$ at $z=1 \mathrm{~m}$ and $360.4 \mathrm{mg} / \mathrm{L}$ at $z=5 \mathrm{~m}$. These values decrease gradually after the closure of the landfill, reaching values of $72.6 \mathrm{mg} / \mathrm{L}(z=1 \mathrm{~m})$ and $51 \mathrm{mg} / \mathrm{L}(z=5 \mathrm{~m})$, twenty years after closure (Table 4). We can calculate (Table 4) how effective the landfill capping is on decreasing leaching of pollutants to the Olt River:

Efficiency $(\%)=a b s\left[\frac{C(x=160 \mathrm{~m}, z, t=30 \text { years })-C(x=160 \mathrm{~m}, z, t=50 \text { years })}{C(x=160 \mathrm{~m}, z, t=30 \text { years }}\right] 100$

We show in Table 4 that the concentration of pollutants reaching the Olt River undergoes a relative decrease of $65 \%, 8$ years after the closure $(t=38$ years) and of $86 \%$ after 20 years 
at all depths. We can therefore claim that the landfill capping is $86 \%$ efficient at decreasing pollution to the Olt River in 20 years after the closure of the landfill ( $t=50$ years).

A significant influence of the landfill is felt up to $20 \mathrm{~m}$ upstream while the landfill is still active, but only up to 1-2 m upstream after 38 years (Fig. 10).

\section{DISCUSSION AND CONCLUSIONS}

In the present work we analyzed the evolution of a chloride pollutant in the aquifer underlying the Râureni landfill: (a) during thirty years of continuous landfill use, assuming a constant leachate concentration $C_{0}$ entering the aquifer (Section 5.1) and (b) twenty years after closure, assuming a linear decrease of the leachate over time as in Fig. 8 (Section 5.2).

For a constant pollutant concentration $C_{0}$ entering the upper boundary of the aquifer, a steady state is achieved in the aquifer in about 3 years. The horizontal and vertical spread of the pollutant plume and the resulting pollution of the Olt River vary with our choice of dispersivity coefficients. A more precise calibration of the dispersivity coefficients, beyond the scale analysis used here necessitates constraining the spread of the plume via a large number of concurrent well measurements. Our study shows that, despite its closure in 2010, the Râreni landfill will continue to influence the aquifer water quality via leaching and pollute the Olt River for at least another twenty years, depending on the quality of the impermeable surface barrier. The concentration of pollutant entering the Olt River will decrease by $65 \%$ eight years after the closure and by $86 \%$ twenty years after the closure.

In follow-up studies we plan to increase the realism of our model by imposing time variable aquifer velocities and concentrations $C_{0}(t)$, which can result from an analysis of (a) the water flow and pollutant transport through the unsaturated porous landfill and (b) the attenuation of pollutant transport due to the fine sand and clay at the base of the waste deposit. Additionally, a retardation factor can be included in the transport equation to account for absorption in soils.

While very simple, our model is highly versatile and can be used beyond this initial study to give an initial prediction of long-term landfill leakage to aquifers under various scenarios for ecological landfill rehabilitation: natural attenuation [18], intensive flushing before final cover installation [19], various capping and aftercare concepts and options [20] such as the expected gradual decrease in the applied barrier efficiency over time [19]. Follow up questions worth pursuing in our model framework include assuming spatially and time varying surface boundary condition for leachate to take into account (a) typical domestic refuse chemical composition in this area and the corresponding rates of biological degradation, (b) seasonal and decadal variation in temperature and precipitation, which have been shown to be distinctly related to the $\mathrm{Cl}^{-}$leachate concentrations [7]. The long-term performance of the Râureni landfill containment system depends on the resistance built into the system and the stresses induced on it.

More complex modeling approaches to verify the long-term environmental compatibility of MSW sites after closure should combine estimations of future pollution hazards such as leakage rates and methane emissions with assessments of the vulnerability of the affected environment (e.g. pollution of groundwater and the nearby Olt River, potential damages to the aquatic ecosystems) [21].

Our model calibration and predictions of leachate behavior at the Râureni landfill are severely limited by the availability of time series at this site. Unfortunately, leachate concentrations at most landfill sites in Romania are only sporadically analyzed, and the results are typically not made publicly available. We strongly recommend the creation of a shared publicly accessible environmental database to be used by the Romanian and international 
scientific community. Better spatial and temporal data coverage of Romanian MSW sites is critical for improving future environmental predictions and management.

Finally, given our model results, we recommend follow-up maintenance (e.g. geotechnical stability, diffuse gas emissions, cultivation layer etc.) and monitoring of the Râureni landfill and of the potentially affected environmental media (e.g. groundwater well, the nearby Olt River) for at least two decades after the landfill closure.

\section{REFERENCES}

[1] Christensen, T.H., Kjeldsen, P., Bjerg, P.L., Jensen, D.L., Christensen, J.B., Baun, A., Albrechtsen, H.-J. \& Heron, G., Biogeochemistry of landfill leachate plumes. Applied Geochemistry, 16(7-8), pp. 659-718, 2001. doi: http://dx.doi.org/10.1016/S08832927(00)00082-2

[2] Kjeldsen, P., Barlaz, M.A., Rooker, A.P., Baun, A., Ledin, A. \& Christensen, T.H., Present and long-term composition of MSW landfill leachate: a review. Environmental Science and Technology, 32 (4), pp. 297-336, 2002. doi: doi: http://dx.doi. org/10.1080/10643380290813462

[3] Öman, C.B. \& Junestedt, C., Chemical characterization of landfill leachates - 400 parameters and compounds. Waste Management, 28(10), pp. 1876-1891, 2008. doi: doi: http://dx.doi.org/10.1016/j.wasman.2007.06.018

[4] Schiopu, A.-M. \& Gavrilescu, M., Options for the treatment and management of municipal landfill leachate: common and specific issues. Clean - Soil, Air, Water, 38(12), pp. 1101-1110, 2010. doi: doi: http://dx.doi.org/10.1002/clen.200900184

[5] Keenan, J.D., Steiner, R.L. \& Fungaroli, A.A., Landfill leachate treatment. Journal Water Pollution Control Federation, 56(1), pp. 27-33, 1984.

[6] Renou, S., Givaudan, J.G., Poulain, S., Dirassouyan, F. \& Moulin, P.P., Landfill leachate treatment: Review and opportunity. Journal of Hazardous Materials, 150(3), pp. 468493, 2008. doi: doi: http://dx.doi.org/10.1016/j.jhazmat.2007.09.077

[7] Statom, R.A., Thyne, G.D. \& McCray, J.E., Temporal changes in leachate chemistry of a municipal solid waste landfill cell in Florida, USA. Environmental Geology, 45 (7), pp. 982-991, 2004. doi: http://dx.doi.org/10.1007/s00254-003-0957-0

[8] Normativul tehnic privind depozitarea deseurilor, construirea, exploatarea, monitorizarea si inchiderea depozitelor de deseuri, 150/07/March/2003, [in romanian]._doi: http:// www.scribd.com/doc/49249998/Normativ-Privind-Depozitarea-Deseurilor.

[9] Romanian law 211/2011 regarding waste material, Monitorul oficial M Of. 837/2011.

[10] Oroian, I. \& Odagiu, A., Evolution of Water Quality in Romania, Studies on Water Management Issues, available at http://www.intechopen.com/books/studies-on-watermanagement-issues/evolution-of-water-quality-in-romania, 2012.

[11] Fetter, C.W., Contaminant Hydrogeology, 2nd edn., Waveland Press, Inc.: Long Grove, IL, p. 58, 2008.

[12] Fried, J.J., Groundwater Pollution, Elsevier S P C: New York, pp. 114-120, 1975.

[13] Sahimi, M., Flow and Transport in Porous Media and Fractured Rock, VCH Velagsgesellschaft mbH: Weinheim, Germany, 1995.

[14] Bijeljic, B., Muggeridge, A.H. \& Blunt, M.J., Pore-scale modeling of longitudinal dispersion. Water Resources Research, 40, p. W11501, 2004.

[15] Bijeljic, B. \& Blunt, M. J., Pore-scale modeling of transverse dispersion in porous media. Water Resources Research, 43, p. W12S11, 2007.

[16] Delgado, J.M.P.Q., Longitudinal and transverse dispersion in porous media. Trans IChemE, Part A, Chemical Engineering Research and Design, 85(A9), pp. 1245-1252, 2007. doi: http://dx.doi.org/10.1205/cherd07017 
[17] Gelhar, L.W., Welty, C. \& Rehfeldt, K.R., A critical review of data on field-scale dispersion in aquifers. Water Resources Research, 28(7), pp. 1955-1974, 1992. doi: http://dx.doi.org/10.1029/92WR00607

[18] Christensen, T.H., Bjerg, P.H. \& Kjeldsen, P., Natural attenuation: A feasible approach to remediation of groundwater pollution at landfills. Ground Water Monitoring and Remediation, 20(1), pp. 69-77, 2000. doi: http://dx.doi.org/10.1111/j.1745-6592.2000. tb00253.x

[19] Laner, D., Fellner, J. \& Brunner, P.H., Future landfill emissions and the effect of final cover installation - A case study. Waste Management, 31(7), pp. 1522-1531, 2011a. doi: http://dx.doi.org/10.1016/j.wasman.2011.02.022

[20] Staub, M.J., Marcolina, G. \& Gourc, J.-P., An incremental model to assess the environmental impact of cap cover systems on MSW landfill emissions. Geotextiles and Geomembranes, 29(3), pp. 298-312, 2011. doi: http://dx.doi.org/10.1016/j.geotexmem.2011.01.013

[21] Laner, D., Fellner, J. \& Brunner, P.H., Environmental compatibility of closed landfills assessing future pollution hazards. Waste Management and Research, 29(1), pp. 89-98, 2011b. doi: http://dx.doi.org/10.1177/0734242X10387655 